\title{
Why is there so much economic insecurity in Latin America?
}

\section{Dani Rodrik}

Harvard University

dani-rodrik@harvard.edu
The view that pervasive economic insecurity threatens political support for the ongoing market-oriented reforms has become one of the most common refrains in current discussions on Latin American affairs. Dealing with economic insecurity would thus appear to be a key part of the unfinished agenda of Latin America's reforms. The author argues that economic insecurity in Latin America is multifaceted and has many sources that feed on each other. Some of the insecurity arises from the decline in employment protection and increased volatility of household outcomes. Some of it is the result of erratic capital flows and the systemic instability generated by a divorce between the instruments of stabilization and the real economy. Finally, an important component is the weakness of the institutions of voice and representation. Programmes aimed at social protection per se can be of partial help only. They will have to be complemented by applying macroeconomic policies, especially with regard to capital flows and the exchange rate, that are more conducive to the stability of the real economy and by loosening the control of financial markets over the instruments of macroeconomic policy. They will also require access to representative institutions -trade unions, political parties, and legislatures- with greater responsiveness and legitimacy than those that exist at present. But perhaps what Latin America needs most is a vision of how social cohesion can be maintained in the face of large inequalities and volatile outcomes, both of which are being aggravated by the growing reliance on market forces. The region will have to develop a vision that finds a way to ease the tension between market forces and the yearning for economic security. 


\section{Introduction}

During the 1990s per capita income in Latin America and the Caribbean grew at an annual average rate of around $2 \%$, after having fallen at a rate of almost $1 \%$ during the 1980s. The performance of the 1990s remains below the pace of economic expansion to which the region was accustomed prior to the debt crisis of 1982. But it does give hope that the continent might be leaving the "lost decade" of the 1980s firmly behind. Nonetheless, the region remains in the grip of a disconcerting level of economic insecurity. The view that pervasive economic insecurity threatens political support for the ongoing market-oriented reforms has become one of the most common refrains in current discussions on Latin American affairs.

The problem is evident in recent surveys undertaken in the region. A large cross-national survey of 14
Latin American countries recently found that $61 \%$ of the respondents thought their parents had lived better than they do. Moreover, less than half of the respondents $(46 \%)$ thought that their children would end up having better lives than themselves, with that percentage varying from as little as 30\% in Mexico to $61 \%$ in Chile (see table 1).

The same survey identified a strong demand for social insurance in the region. Almost three-quarters of the respondents favoured increased spending on unemployment insurance, and more than $80 \%$ expressed a desire for more spending on pensions. Moreover, these demands cut across social groups. The preference for greater spending on pensions and unemployment insurance varied very little with the respondents' level of income, education and type of

TABLE 1

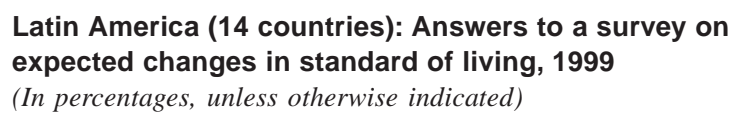

\begin{tabular}{|c|c|c|c|c|c|c|c|c|c|c|c|c|c|c|c|}
\hline \multicolumn{3}{|c|}{ Total } & \multicolumn{11}{|c|}{ Countries } & \multirow[b]{2}{*}{$\begin{array}{l}\text { Uru- } \\
\text { guay }\end{array}$} & \multirow[b]{2}{*}{$\begin{array}{l}\text { Vene- } \\
\text { zuela }\end{array}$} \\
\hline Number & $\%$ & $\begin{array}{l}\text { Argen- } \\
\text { tina }\end{array}$ & $\begin{array}{c}\text { Boli- } \\
\text { via }\end{array}$ & $\begin{array}{c}\text { Bra- } \\
\text { zil }\end{array}$ & $\begin{array}{l}\text { Colom- } \\
\text { bia }\end{array}$ & $\begin{array}{l}\text { Costa } \\
\text { Rica }\end{array}$ & Chile & $\begin{array}{l}\text { Ecua- } \\
\text { dor }\end{array}$ & $\begin{array}{l}\text { Guate- } \\
\text { mala }\end{array}$ & $\begin{array}{l}\text { Mexi- } \\
\text { co }\end{array}$ & $\begin{array}{l}\text { Pana- } \\
\text { ma }\end{array}$ & $\begin{array}{l}\text { Para- } \\
\text { guay }\end{array}$ & Peru & & \\
\hline 14839 & 100 & 1200 & 794 & 1000 & 1200 & 1000 & 1200 & 1200 & 1000 & 1200 & 1000 & 600 & 1045 & 1200 & 1200 \\
\hline
\end{tabular}

Taking everything into consideration, would you say that your parents lived better, the same or worse than you live today?

\begin{tabular}{|c|c|c|c|c|c|c|c|c|c|c|c|c|c|c|c|}
\hline Better & 9081 & 61.2 & 63 & 51 & 64 & 78 & 56 & 45 & 67 & 57 & 43 & 52 & 75 & 80 & 59 \\
\hline The same & 3261 & 22 & 22 & 31 & 9 & 14 & 26 & 32 & 20 & 31 & 35 & 24 & 14 & 12 & 18 \\
\hline Worse & 2139 & 14.4 & 12 & 16 & 25 & 8 & 14 & 22 & 10 & 11 & 20 & 21 & 6 & 6 & 20 \\
\hline No answer & 358 & 2.4 & 3 & 3 & 2 & 1 & 5 & 1 & 2 & 1 & 3 & 3 & 5 & 2 & 3 \\
\hline
\end{tabular}

With regard to your children, do you think they will live better, the same or worse than you live today?

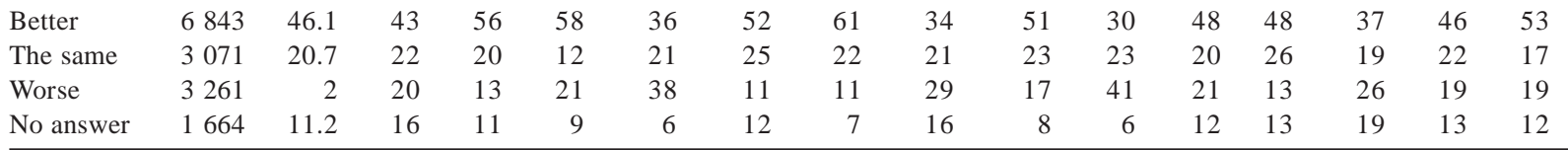

Source: Mirror on the Americas Poll (1999), Wall Street Journal Interactive Edition.

This paper was originally prepared for and funded by the World Bank. I am grateful to Guillermo Perry for asking me to do this paper, and to Jorge Domínguez, Nora Lustig, Norman Hicks, Bill Maloney, Guillermo Perry, Martín Rama, Guilherme Sedlacek, Luis Serven and Mariano Tommasi for very useful comments on an ear- lier draft. Vladimir Kliouev provided expert research assistance. None of these individuals, however, and least of all the World Bank, should be considered as having any responsibility for the views expressed herein. 
Latin America (14 countries): Answers to a survey on aspects connected with social security, by socioeconomic category ${ }^{a}$

(In percentages, unless otherwise indicated)

\begin{tabular}{|c|c|c|c|c|c|c|c|c|c|c|c|c|c|c|c|c|c|c|}
\hline & \multicolumn{2}{|c|}{ Total sample } & \multicolumn{3}{|c|}{ Age } & \multicolumn{6}{|c|}{ Employment } & \multicolumn{4}{|c|}{ Education } & \multicolumn{3}{|c|}{ Income } \\
\hline & No. & $\%$ & $\begin{array}{l}18- \\
29\end{array}$ & $\begin{array}{c}30- \\
49\end{array}$ & $50+$ & $\begin{array}{l}\text { Self- } \\
\text { em- } \\
\text { ployed }\end{array}$ & $\begin{array}{l}\text { Gov- } \\
\text { ern- } \\
\text { ment }\end{array}$ & $\begin{array}{l}\text { Priv- } \\
\text { ate } \\
\text { sector }\end{array}$ & $\begin{array}{l}\text { Unem- } \\
\text { ployed }\end{array}$ & $\begin{array}{l}\text { Reti- } \\
\text { red }\end{array}$ & $\begin{array}{l}\text { House- } \\
\text { wife }\end{array}$ & $\begin{array}{c}\text { No } \\
\text { schooling }\end{array}$ & $\begin{array}{l}\text { Prim- } \\
\text { ary }\end{array}$ & $\begin{array}{l}\text { Secon- } \\
\text { dary }\end{array}$ & $\begin{array}{l}\text { Univ- } \\
\text { ersity }\end{array}$ & Low & Middle & High \\
\hline \multicolumn{19}{|l|}{$\begin{array}{l}\text { Unemployment } \\
\text { insurance }\end{array}$} \\
\hline No answer & 551 & 3.7 & 3 & 4 & 4 & 4 & 5 & 3 & 3 & 4 & 4 & 3 & 4 & 3 & 4 & 4 & 4 & 3 \\
\hline Spend more & 10088 & 73.4 & 74 & 73 & 73 & 74 & 69 & 74 & 80 & 74 & 73 & 74 & 74 & 75 & 71 & 72 & 73 & 74 \\
\hline Spend less & 2543 & 17.1 & 18 & 18 & 16 & 17 & 19 & 17 & 13 & 16 & 17 & 19 & 16 & 16 & 19 & 19 & 17 & 17 \\
\hline Don't know & 857 & 5.8 & 5 & 5 & 7 & 5 & 7 & 6 & 3 & 6 & 7 & 5 & 7 & 5 & 6 & 4 & 6 & 6 \\
\hline \multicolumn{19}{|l|}{ Pensions } \\
\hline No answer & 172 & 1.2 & 1 & 1 & 1 & 1 & 2 & 1 & 1 & 1 & 1 & 1 & 1 & 1 & 1 & 2 & 1 & 1 \\
\hline Spend more & 12426 & 83.7 & 83 & 83 & 86 & 83 & 84 & 84 & 88 & 88 & 84 & 82 & 83 & 85 & 83 & 83 & 85 & 83 \\
\hline Spend less & 1861 & 12.5 & 13 & 13 & 10 & 13 & 12 & 13 & 9 & 9 & 12 & 15 & 13 & 12 & 14 & 14 & 11 & 13 \\
\hline Don't know & 380 & 2.6 & 3 & 3 & 3 & 3 & 2 & 2 & 1 & 2 & 3 & 2 & 3 & 2 & 2 & 2 & 2 & 3 \\
\hline \multicolumn{19}{|l|}{$\begin{array}{l}\text { Defence and } \\
\text { armed forces }\end{array}$} \\
\hline No answer & 623 & 4.2 & 4 & 5 & 5 & 4 & 6 & 3 & 3 & 5 & 4 & 3 & 4 & 4 & 5 & 5 & 5 & 3 \\
\hline Spend more & 4810 & 32.4 & 33 & 31 & 34 & 34 & 28 & 29 & 36 & 33 & 35 & 32 & 37 & 33 & 27 & 32 & 31 & 34 \\
\hline Spend less & 8359 & 56.3 & 58 & 57 & 53 & 56 & 59 & 60 & 56 & 54 & 52 & 60 & 50 & 57 & 62 & 58 & 56 & 57 \\
\hline Don't know & 1047 & 7.1 & 5 & 7 & 9 & 6 & 7 & 7 & 5 & 8 & 9 & 5 & 8 & 7 & 7 & 6 & 8 & 7 \\
\hline
\end{tabular}

Source: Mirror on the Americas Poll (1999), Wall Street Journal Interactive Edition.

a The text of the question was: "Do you believe that in your country it would be better to spend more or less on each of the following items?".

employment (table 2). Predictably, the demand for social insurance tends to be larger in countries where greater pessimism prevails regarding the future. But there are interesting exceptions. In Mexico, demands for greater spending on social insurance are muted despite a high level of pessimism about the next generation's prospects. In Chile, meanwhile, where expectations are reasonably upbeat, the percentage of respondents who favour greater spending reaches $85 \%$ in the case of unemployment insurance and $93 \%$ in the case of pensions.

Do these numbers mean anything? One indication that they do comes from the responses to the other questions in the survey. For example, when the same individuals were asked about national defence and the armed forces, less than a third replied that they would like to see an increase in spending on them (table 2). This shows that the respondents made a clear distinction between economic security and national security, and ranked the former significantly above the latter. Another indication comes from comparing results of similar surveys in other settings. When surveys of this kind are undertaken in the advanced industrial countries, the proportions of respondents that favour increased spending on pensions and unemployment benefits tend to be significantly lower than the numbers reported above. Moreover, the proportions vary significantly according to income levels. ${ }^{1}$ A poignant example from Brazil was recently highlighted in the New York Times, which reported that as many as one million people (one out of every 160 Brazilians) were competing in August 1999 for 10,000 desk jobs at the Banco do Brasil, a government-run institution that "pays salaries on time and in full" and provides comprehensive health insurance and pension benefits. "I need stability in my life", a 23-year old job applicant was quoted as saying when asked why she applied for a job that actually pays less than her present salary (Romero, 1999). Dealing with economic insecurity would appear to be a key part of the unfinished agenda of Latin America's reforms.

\footnotetext{
${ }^{1}$ For some comparative evidence, see Taylor-Gooby (1989).
} 
How can policy-makers progress in this? A first step is to understand the root causes of economic insecurity. In this paper I highlight the role of three sets of critical contributory factors. First, we must begin with the trauma of the 1980s. The deep recession that most of the countries of the region experienced in the aftermath of the debt crisis is reminiscent in some ways of the Great Depression in the United States during the 1930s. While the Great Depression resulted in a steeper fall in incomes, the recovery was more rapid as well. In the United States, the hardships caused by the Depression, and especially the losses suffered by the middle classes, stimulated a set of government programmes -collectively known as the New Dealwhich greatly expanded the role of the government, established social safety nets, and provided social insurance. In Latin America, the upshot of the debt crisis was a series of reforms that actually served to weaken social insurance institutions. Employment generally became less secure, and publicly provided safety nets were weakened.

Second, as Latin America entered the 1990s it found itself in a world of high macroeconomic volatility, which was driven in large part by erratic capital flows, or at least magnified by them. The spread of international financial markets and the region's enthusiastic embrace of them left macroeconomic policy dependent on (and often hostage to) the fancies of short-term investors. Key instruments such as fiscal policy and the exchange rate became overwhelmed by the need to manage capital flows and could no longer be targeted at domestic stability. Macroeconomic policy became increasingly divorced from the real economy. This has exacerbated the volatility of economic outcomes both over time and across households.

Third, a key shortcoming in Latin America is that social and political institutions have not been adequately responsive so far to the clamour for greater economic security. As mentioned above, States have retrenched rather than taken on the added responsibilities that managing risk in market-oriented societies requires. But the problem goes beyond governments. Political sys- tems as a whole have failed to create viable mechanisms of voice: national legislatures have been fragmented and unrepresentative, and political parties weak. Trade unions have been unable to develop an adequate and encompassing strategy for dealing with job insecurity and have lost members. And the monopolization of policy discussions around a narrow, Washington Consensus-based view of development policy, sharply constrained by the "requirements" of global economic integration, has prevented the emergence of an alternative (or at least complementary) vision of economic reform driven by local concerns and national aspirations.

I will discuss these issues and their policy implications in the rest of the paper. But a key caveat needs to be mentioned at the outset. The focus in this paper is not on the poor and most vulnerable per se. I do not deal with anti-poverty policy, nor do I discuss how to reduce the vulnerability of the poor to volatility and shocks. ${ }^{2}$ The Latin American poor have always been excluded and vulnerable. What seems to be new is that the fear of downward mobility now affects a large part of the middle classes as well. The survey mentioned earlier reveals that in some of the largest countries of Latin America -Argentina, Brazil, Mexico and Venezuela in particular- the middle-income groups are more pessimistic about their children's future than the lowestincome groups. Indeed, that is what gives the demand for "social protection" its political salience in the region. My focus will be on this broader notion of economic insecurity and its consequences.

Finally, I should emphasize that the purpose of this paper is to stimulate discussion, suggest hypotheses and lay out an agenda for further research, just as much as it is to present specific arguments with supporting evidence. Many of my arguments below remain speculative. The empirical "tests" that I do present are suggestive rather than definitive. But if the paper helps open new lines of inquiry it will have achieved its objective.

\footnotetext{
${ }^{2}$ For a good set of essays on these issues, see Lustig (ed.), 1995.
} 
II

\section{The trauma of the 1980s}

The debt crisis of 1982 engulfed Latin America in a deep and prolonged recession. Figure 1 shows an index of per capita income in the leading countries of the region, comparing their experience with that of the United States during the Great Depression. In the United States, incomes declined on average by $35 \%$ between 1929 and 1933, and unemployment peaked at $25 \%$ (in 1933). As figure 1 shows, the decline in real incomes (and rise in unemployment) was not as steep in Latin America after 1981: it was of the order of $20 \%$ in Argentina, Chile, Mexico and Venezuela, and $10 \%$ in Brazil. Among the major countries, only Peru (thanks to President García's disastrous policies) experienced an income collapse of the same magnitude as that suffered by the United States in the Great Depression. However, with the notable exception of Chile, the recovery in Latin America was also more gradual. It took 10 years in the United States for per capita income to recover to its pre-crisis level. In Argentina and Brazil, it took 12 and 13 years respectively, and in Mexico, Peru and Venezuela per capita incomes were still below 1981 levels in 1997 (the latest year for which national income estimates were available (World Bank, 1999). Moreover, the United States economy, boosted in part by the Second World War, experienced a much faster rate of expansion in the 1940s than it had during the 1920s. Latin America's growth rate during the 1990s, however, has failed to match the record of the 1960s and 1970s.

The United States responded to the Great Depression with a series of major institutional innovations that greatly expanded the role of the government in the economy and for the most part represented a sharp break with the past. Many of these innovations took the form of social insurance (Bordo, Goldin and White (eds.), 1998, page 6): social security, unemployment compensation, public works, public ownership, deposit insurance and legislation favouring unions were among the new mechanisms created to deal with the perceived shortcomings of the private marketplace. As Jacoby (1998) notes, prior to the Great Depression the middle classes were generally able to self-insure or buy insur-

FIGURE 1

Comparison between Latin America after 1981 and the United States in the Great Depression: Decline in real per capita income

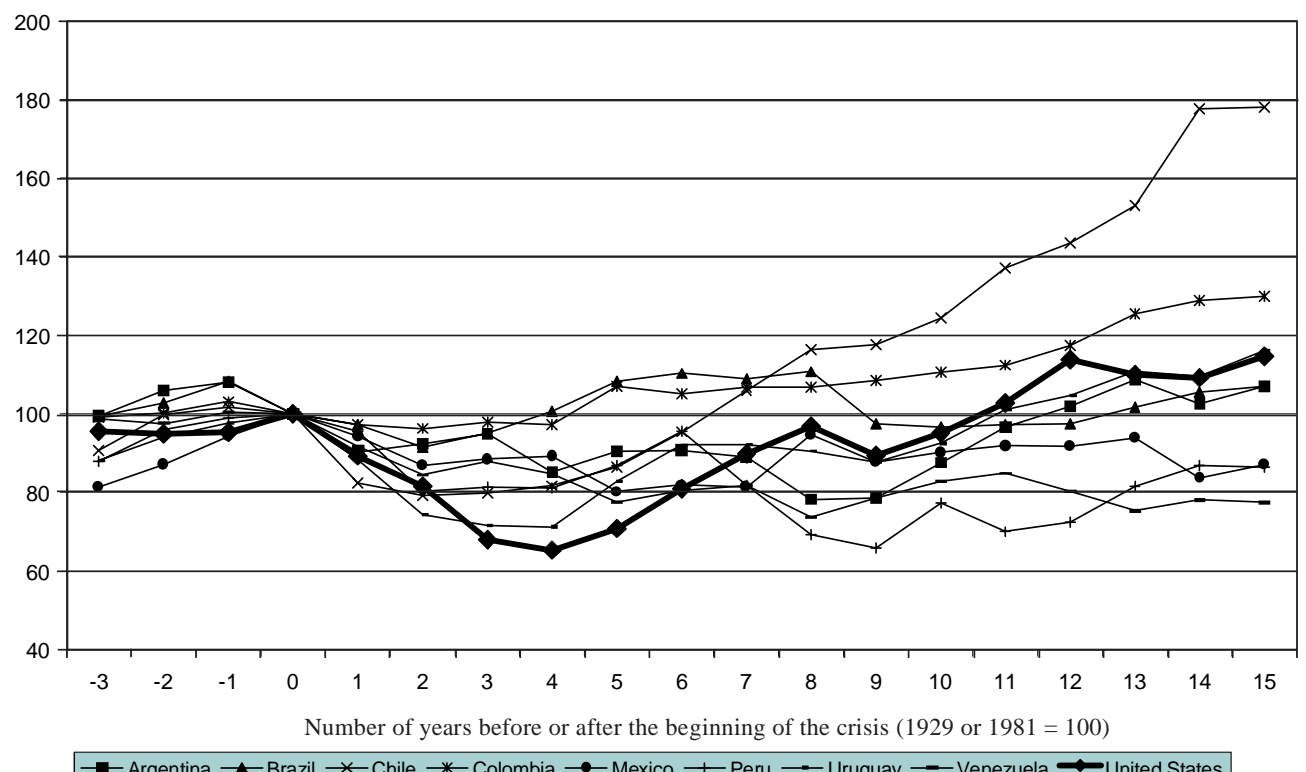

Argentina $₫$ Brazil $\rightarrow$ Chile $\rightarrow$ Colombia $\rightarrow$ Mexico $\multimap$ Peru $\longrightarrow$ Uruguay - Venezuela $\multimap$ United States 
ance from private intermediaries. As these private forms of insurance collapsed, the middle classes threw their considerable political weight behind the extension of social insurance and the creation of what would later be called the Welfare State.

The Great Depression had two effects: first, it undermined middle-class trust in the private system for handling labour market risks; the collapse of "welfare capitalism", combined with mass layoffs and bank failures, created a crisis of confidence that caused middle-class Americans to mobilize in search of alternatives. Second, it caused the middle class to perceive its social status as precarious; actual or threatened downward mobility narrowed the social distance between the middle class and those below, making cross-class alliances more likely and weakening resistance to redistributive programmes that could benefit the downwardly mobile. In short, the experiences of the 1930s and 1940s inclined the American middle classes to favour social solidarity over rugged individualism: a shift that promoted the Welfare State, public education, and other forms of government expenditure (Jacoby, 1998, pp. 29-31).

Note the parallels with the Latin American experience in the aftermath of the debt crisis. As in the case of the United States, the crisis of the 1980s placed great strains on private insurance arrangements in Latin America. For example, Glewwe and Hall (1998) find in their analysis of Peru that inter-household transfer networks collapsed almost in their entirety during the second half of the 1980s. Since transfer-making households suffer during major crises too, private systems of income support tend not to be very resilient to macro shocks. And one implication of the generalized crisis was that, as noted in the introduction, social insurance has become a middle-class preoccupation in Latin America as well.

But there was also an ideological underpinning for the growth of government programmes in the United States. Rockoff (1998) has argued that the change in attitudes towards the role of the government was facilitated in the United States by an ideological shift among economists from laissez-faire to interventionism dating at least from a decade prior to the Great Depression. While macroeconomists tended to be conservative, microeconomists "championed a long list of reforms such as minimum wages, employment exchanges, old-age pensions, publicly owned regional power utilities, and so on" (Rockoff, 1998, p. 134). Hence ideology and interests coincided in spurring the adoption of social insurance programmes.
In terms of the role of government, Latin America entered the 1980s from a very different vantage point from that of the United States at the beginning of the 1930s. Most of the countries of the region had industrialized behind the protection of government-imposed trade restrictions, public enterprises had become commonplace, and fiscal deficits and macroeconomic mismanagement were the proximate causes of the debt crisis. Governments were seen as part of the problem rather than as the solution. And just as in the case of the United States, academic opinion had been largely transformed during the 1970 s, but this time in the direction of favouring markets over government intervention.

The reforms that Latin America adopted in the 1980s and thereafter were correspondingly aimed at enhancing the scope of the market and reining in that of government. Privatization, deregulation, trade liberalization and financial liberalization were key items in the Washington Consensus. Public opinion surveys, like those cited earlier, generally show that a majority of Latin Americans prefer markets and the private enterprise system to government control. However, what is important from our perspective is the complete absence from the Washington Consensus agenda of prescriptions aimed at combatting economic insecurity.

This is especially striking in view of the fact that many of the market-oriented reforms had the predictable effect of increasing risk for workers and households. Privatization, deregulation and trade liberalization all entailed restructuring of the economy and greater risk of job loss, at least in the short run. The retrenchment of the public sector meant reduced opportunities for relatively safe public employment. Financial liberalization could be counted upon to generate volatility in the economic environment. Greater capital mobility implied the shifting of idiosyncratic country risk from mobile capital to immobile labour. It is only recently that the importance of such effects has come to be recognized.

We can therefore presume that the economic insecurity generated by the prolonged debt crisis was only amplified by the market-oriented reforms that all the countries of the region eventually adopted without instituting complementary programmes of social insurance. Whereas the response to the Great Depression in the United States was a significant strengthening of social protection, the response to the debt crisis in Latin America was a weakening of social insurance in the face of increased labour-market risks. 


\section{III}

\section{The decline of job security}

While many of the reforms undertaken in Latin America could have been expected to raise job insecurity, at least in the short run, direct evidence on this is not easy to come by. Measures of involuntary job displacement are not widely available, and in any case are contaminated by the behavioral responses that economic insecurity generates: workers who feel less secure are more likely to accept wage reductions or make other concessions to avoid losing their jobs. Furthermore, there has not been much change in formal legislation on employment protection, despite much talk about the need to render labour markets more "flexible" (Márquez and Pages, 1998). Nonetheless, the available evidence does suggest that the proportion of workers with "secure" jobs has declined practically in all of the countries of the region for which relevant data exist.

One indication of this is the sharp reduction in trade union density since the 1980s, in all countries except Chile. This is significant, since bargaining for greater job security on behalf of their members is a key function of trade unions. Table 3 presents statistics from the International Labour Organisation (ILO) on trade union membership and trade union density for ten Latin American countries. Wherever a comparison between the 1980 s and 1990 s is possible, the numbers typically reveal a sharp decline. In Argentina, for example, the percentage of the non-agricultural labour force represented by unions has fallen from $49 \%$ in 1986 to $25 \%$ in 1995. In Mexico, the corresponding percentage went down (if the statistics are to be believed) from $54 \%$ to $31 \%$ in the span of two years (1989 to 1991). Chile, where the demise of Pinochet's rule and the transition to democracy resulted in an initial jump in trade union membership and density, is the sole exception to the rule. However, even in Chile more recent figures show that union membership ratios have declined since the early 1990s, and are currently back at pre-democracy levels. ${ }^{3}$

Table 3 also shows another indicator of job insecurity: the proportion of workers who are not "protected" by formal written contracts or inclusion in social

\footnotetext{
${ }^{3}$ Chilean Ministry of Labour figures, as reported in The Economist Intelligence Unit (1998).
}

benefit programmes. The definition of unprotected employment, taken from ILO (1999), is somewhat slippery, and refers to different things in different countries. For example, the Argentine figures relate to private employees without written contract as a share of total private employment in Greater Buenos Aires. In Bolivia, the numbers are for those not covered by labour and social legislation, as a share of total salaried employment. The Brazilian figures (taken from Ferreira and Paes de Barros, 1999) are for employees without carteira as a fraction of all wage employees and selfemployed workers.

In all seven countries where a comparison between two points in time is possible, the numbers reveal an upward jump in "unprotected" employment: from $22 \%$ to $34 \%$ in Argentina, from $64 \%$ to $69 \%$ in Brazil, from $44 \%$ to $50 \%$ in Mexico. This time Chile is no exception to the trend (with an increase from $17 \%$ to $22 \%$ ). Note that these proportions cannot be compared across countries, since the samples covered vary greatly, and the absolute shares in themselves are not very meaningful (unlike the changes therein). Since the denominators typically cover more privileged workers (in urban areas or those that are salaried), the absolute numbers represent in most cases an underestimation of the proportion of unprotected workers. The oft-repeated statement that the informal economy accounts for $80 \%$ of the new jobs created in Latin America over the last two decades (see for example ILO, 1999) provides a complementary perspective to these findings. ${ }^{4,5}$

Since the legislation itself has not changed much, these trends have to be interpreted as the endogenous responses of the economy to the joint shocks of the debt crisis and structural reform. In Chile, for example,

\footnotetext{
${ }^{4}$ The extent to which the decline in the share of formal sector employment is the outcome of restrictive employment legislation -such as minimum wages and mandatory benefits- remains debatable. Amadeo and Camargo (1997) argue in the Brazilian context that such legislation is only a small part of the story. Pessino (1997) provides an alternative perspective on Argentina.

${ }^{5}$ Note that informal sector employment, despite generally lower levels of employment security, need not imply worse outcomes for workers. In many cases, workers may prefer informality so as to avoid paying income and other taxes.
} 
TABLE 3

Latin America (10 countries): Indicators of employment security

\begin{tabular}{|c|c|c|c|c|c|c|}
\hline \multirow[b]{2}{*}{ Argentina } & \multicolumn{2}{|c|}{$\begin{array}{l}\text { Trade union membership } \\
\text { (thousands) }\end{array}$} & \multicolumn{2}{|c|}{$\begin{array}{c}\text { Trade union coverage } \\
\text { (as \% of non-agricultural } \\
\text { workers) }\end{array}$} & \multicolumn{2}{|c|}{$\begin{array}{c}\text { "Unprotected" employment } \\
\text { (as a percentage } \\
\text { of number of workers) }\end{array}$} \\
\hline & 1986 & 3262 & 1986 & 48.7 & 1990 & 21.7 \\
\hline & 1995 & 3200 & 1995 & 25.4 & 1996 & 34 \\
\hline \multirow[t]{2}{*}{ Bolivia } & 1994 & 276 & 1994 & 16.4 & 1991 & 28 \\
\hline & & & & & 1997 & 34.8 \\
\hline \multirow[t]{2}{*}{ Brazil } & 1991 & 15205 & 1991 & 32.1 & 1985 & 63.6 \\
\hline & & & & & 1996 & 68.5 \\
\hline \multirow[t]{2}{*}{ Chile } & 1985 & 361 & 1985 & 11.6 & 1990 & 17 \\
\hline & 1993 & 684 & 1993 & 15.9 & 1996 & 22.3 \\
\hline \multirow[t]{2}{*}{ Colombia } & 1985 & 877 & 1985 & 11.2 & & \\
\hline & 1995 & 840 & 1995 & 7.0 & & \\
\hline \multirow[t]{2}{*}{ El Salvador } & 1985 & 79 & 1985 & 7.9 & 1994 & 59.1 \\
\hline & 1995 & 103 & 1995 & 7.2 & 1997 & 61.3 \\
\hline \multirow[t]{2}{*}{ Mexico } & 1989 & 9500 & 1989 & 54.1 & 1990 & 43.4 \\
\hline & 1991 & 7000 & 1991 & 31.0 & 1997 & 49.6 \\
\hline \multirow[t]{2}{*}{ Peru } & 1991 & 442 & 1991 & 7.5 & 1990 & 25.2 \\
\hline & & & & & 1996 & 34.1 \\
\hline \multirow[t]{2}{*}{ Uruguay } & 1990 & 222 & 1990 & 19.9 & & \\
\hline & 1993 & 151 & 1993 & 11.6 & & \\
\hline \multirow[t]{2}{*}{ Venezuela } & 1988 & 1700 & 1988 & 25.9 & & \\
\hline & 1995 & 1153 & 1995 & 14.9 & & \\
\hline
\end{tabular}

Source: ILO, 1997, tables 1.1 and 1.2; ILO, 1999, table 7; Ferreira and Paes de Barros, 1999, table 1.

a The term "unprotected" employment refers to the proportion of private sector or urban workers without a contract or social security benefits in each country. See ILO, 1999, table 7 for the original sources and more details.

the period since the debt crisis has witnessed historically high levels of labour turnover. Moreover, trade liberalization has resulted in the expansion of activities (forestry and agriculture in particular) where longterm contract employment is less common and selfemployment more so than in traditional activities (such as copper mining and manufacturing). The expansion of exports has also been associated with greater subcontracting, which generally shifts risk to small enterprises and the self-employed. In forestry, an impressive export performance has been "accompanied by a type of work organization characterized by a high share of subcontracting activities and employment instability" (ILO, 1998). In Brazil, labour turnover remains quite high by European or even U.S. standards, a situation that Amadeo and Camargo (1997) characterize as a case of "excessive" employment flexibility.

Has the evident decline in job protection been compensated by lower rates of unemployment overall? The empirical literature on the relationship between termination costs and unemployment rates does not yield strong conclusions. The cross-national evidence generally suggests that the first-order effects of employment protection are distributional: the beneficiaries tend to be older, male workers, while younger, female workers lose out. But the relaxation of job protection legislation appears to have weak effects on overall levels of employment. The limited evidence from Latin America is consistent with such findings (Márquez and Pages, 1998).

Table 4 displays unemployment rates for 16 Latin American countries for three sub-periods since 1981 (1981-1988, 1989-1993, and 1994-1998). For most countries, unemployment exhibits a U-shaped pattern. The early years following the debt crisis were generally a period of high unemployment. Unemployment fell during the late 1980s, but has subsequently risen since the mid-1990s. Brazil, Mexico, Uruguay and 
TABLE 4

Latin America (16 countries): Rates of unemployment (Percentages)

\begin{tabular}{lrrr}
\hline & $1981-1988$ & $1989-1993$ & $1994-1998$ \\
\hline Argentina & 5.4 & 7.6 & 15.3 \\
Bolivia & 7.6 & 6.9 & 3.6 \\
Brazil & 5.6 & 4.7 & 5.7 \\
Chile & 14.9 & 7.2 & 7.6 \\
Colombia & 11.6 & 9.9 & 10.4 \\
Costa Rica & 6.2 & 4.4 & 5.4 \\
Ecuador & 8.2 & 8.1 & 8.8 \\
El Salvador & 9.4 & 8.5 & 7.2 \\
Guatemala & 9.1 & 4.1 & 4.0 \\
Honduras & 10.3 & 7.1 & 5.6 \\
Mexico & 4.0 & 2.9 & 4.8 \\
Nicaragua & 13.0 & 14.7 & 16.5 \\
Paraguay & 5.6 & 5.6 & 6.0 \\
Peru & 6.9 & 8.3 & 7.8 \\
Uruguay & 11.3 & 8.8 & 10.8 \\
Venezuela & 10.4 & 8.4 & 10.5 \\
\hline
\end{tabular}

Source: Inter-American Development Bank (IDB, undated).
Venezuela all exhibit this distinctive pattern. But there are also exceptions. In Chile, unemployment has remained well below the levels of the early to mid-1980s. In Argentina, unemployment has increased more or less steadily since the early 1980s for workers at all skill levels (Pessino, 1997). It is striking that half of the countries in the table (eight out of sixteen) had higher unemployment rates in 1994-1998 than they did during 1981-1988 (Argentina, Brazil, Ecuador, Mexico, Nicaragua, Peru, Paraguay and Venezuela).

Therefore the decline in job protection has been accompanied by rising unemployment levels during the 1990s in most countries of the region. While it is possible that unemployment would have risen to greater heights had unions not lost membership and other forms of job protection not weakened, the international evidence suggests that this is not a very likely scenario. The risks of job loss followed by a period of unemployment seem to have clearly increased.

\section{IV}

\section{Macroeconomic volatility and its relation to household incomes: a decomposition}

While the fear of drastic reduction in income associated with job loss and unemployment is an important component of economic insecurity, another is sheer volatility of the household income stream. As Gavin and Hausmann (1996) have emphasized in their work, Latin America is a volatile region, where the standard deviation of GNP growth rates tends to be on average around twice the level observed in industrial economies. For individual households, what matters is the volatility of their own income streams. While, by definition, not all households can successfully shield themselves from the average volatility of the economy (as captured in movements of aggregate GNP), the distribution of uncertainty across households does depend on the degree to which household risks vary with national output. $^{6}$

We can express the relationship between household and national income volatility using a simple decomposition based on the identity:

${ }^{6}$ For the purposes of this discussion, I shall treat national income and GNP interchangeably.

$$
d \ln y_{i t}=d \ln y_{t}+\left(d \ln y_{i t}-d \ln y_{t}\right)
$$

where $y_{i t}$ and $y_{t}$ are household and national incomes at time $t$, and $d \ln y_{i t}$ and $d \ln y_{t}$ are the growth rates of the $i$ th household's income and of GNP, respectively. Let us define the household and national growth rates as:

$$
\begin{aligned}
d \ln y_{i t} & =\delta_{i t} \\
d \ln y_{t} & =\delta_{t}
\end{aligned}
$$

Furthermore, let the household's income growth rate relative to the national average be given by:

$$
\left(d \ln y_{i t}-d \ln y_{t}\right)=\rho_{i t}
$$

Now we can decompose the volatility of the $i$ th household's income growth into three separate terms.

$$
\sigma_{\delta_{i}}^{2} \equiv \sigma_{\delta}^{2}+\sigma_{\rho_{i}}^{2}+2 \operatorname{cov}\left(\rho_{i t}, \delta_{t}\right) .
$$

The first term represents the volatility of the national economy $\left(\sigma_{\delta}^{2}\right)$. This term captures the macro shocks 
that affect the economy and is the volatility on which the work by Gavin and Hausmann (1996) focuses. The second term is the volatility of relative household incomes $\left(\sigma_{\rho_{i}}^{2}\right)$. This captures the purely idiosyncratic shocks that hit a given household. Finally, the third term is the covariance between the growth rates of GNP and a household's relative incomes $\left(\operatorname{cov}\left(\rho_{i t}, \delta_{t}\right)\right)$. This term will be positive whenever a household's relative income is pro-cyclical: i.e., when the household's income grows faster than the average in good times for the national economy and slower than the average in bad times. Obviously, the third term cannot have the same sign for all households in the economy. Lustig (1999) cites studies showing that for every one percentage point decline in growth, poverty rises by $2 \%$. If the poor are more vulnerable to economic downturns, as these studies indicate, the third term will be positive for households at the bottom of the income distribution and negative for households at the top.

The decomposition is useful in that it helps organize our thinking on how uncertainty at the household level can best be tackled. It highlights three sources of uncertainty with three different kinds of implications for policy. If most of the uncertainty is at the macro level, improving the quality of macroeconomic policymaking would be the most direct and effective way of reducing household risk. If most of it is instead idiosyncratic, specific to individual households, what is needed is insurance pure and simple (whether provided privately or through the government). If a considerable amount of it originates from the excessive susceptibility of particular households to macroeconomic downswings, then the appropriate response consists of identifying those households and making sure that transfer mechanisms are (a) appropriately targeted and (b) resilient to macro shocks. ${ }^{7}$

Carrying out this decomposition requires repeated household panels, which do not exist for many countries. Peru's Living Standards Measurement Surveys do provide data in panel form. They have been used by Glewwe and Hall (1998) for the purpose of identifying the households that are more vulnerable to shocks.

In order to show how the decomposition can be put to work, I will now undertake a very rough exercise based on easily obtainable data on average real

\footnotetext{
${ }^{7}$ See Lustig (1999), especially on the design of poverty-sensitive responses to adverse shocks. Lustig calls for the institution of counter-cyclical safety nets to protect the poor from excessive vulnerability to economic downswings.
}

wages. The exercise consists of making illustrative calculations for an "average" worker household. We consider a household whose sole source of income is wages, and which earns the average wage in the economy and cannot vary the hours worked. Then the relevant volatility decomposition for this household can be written as follows:

$$
\sigma_{w}^{2}=\sigma_{\delta}^{2}+\sigma_{\rho}^{2}+2 \operatorname{cov}(\rho, \delta),
$$

where $\sigma_{w_{2}}^{2}$ stands for the volatility of real wage growth, $\sigma_{\rho}^{2}$ for the volatility of real wages relative to GNP, and the other terms have the obvious interpretations. As before, the equation decomposes the volatility of the average worker's earnings into three components: a macro term, an idiosyncratic term, and a covariance term.

Note an important caveat here: Basing the calculations on an economy-wide average wage defeats the purpose of the decomposition methodology in that it clouds the distinction between idiosyncratic and macro risks. The incidence of risk among workers is ignored. The only source of idiosyncratic risk that this particular calculation can capture is that which affects average (formal-sector) labour income relative to other sources of income. For that reason, the exercise cannot be interpreted as giving an accurate guide to the magnitude of idiosyncratic versus macro risks. It is only an illustrative guide to the experience of an "average" worker.

Table 5 shows the calculations for four countries (Chile, Mexico, Peru and Venezuela), selected according to the availability of real wage data. For each country, the calculations are shown for two sub-periods since the early 1980s. The main result that comes across in table 5 is the difference between Chile and the other countries in the sample. First, the volatility of real wages has increased greatly in the 1990s in all countries but Chile. In Chile's case wage growth has been considerably more stable in the period since the 1980s collapse. Second, the growth of wages relative to national income is either pro-cyclical (Peru) or has become so in the 1990s (Mexico and Venezuela) in all countries but Chile. In other words, macroeconomic volatility is transmitted on to wages in these countries in a magnified manner. Third, for the average worker, the "idiosyncratic" component of wage volatility accounts for around half or less of total wage volatility in the three countries other than Chile. Hence, macro shocks and their interaction with wage movements are a major -if not the major-part of wage uncertainty in Mexico, Peru 
TABLE 5

Latin America (4 countries): Decomposition of volatility of real wages ${ }^{\text {a }}$

\begin{tabular}{|c|c|c|c|c|c|c|c|c|c|}
\hline & \multirow[b]{2}{*}{ Periods } & \multicolumn{2}{|c|}{$\operatorname{Var}(d \ln w)$} & \multicolumn{2}{|c|}{$\operatorname{Var}(d \ln y)$} & \multicolumn{2}{|c|}{$\operatorname{Var}(d \ln w-d \ln y)$} & \multicolumn{2}{|c|}{$2 x \operatorname{cov}(d \ln y, d \ln w-d \ln y)$} \\
\hline & & Value & $\%$ & Value & $\%$ & Value & $\%$ & Value & $\%$ \\
\hline \multirow[t]{2}{*}{ Chile } & 1981-1986 & 2.13 & 100 & 0.77 & 36 & 3.13 & 147 & -1.77 & -83 \\
\hline & 1987-1992 & 0.22 & 100 & 0.13 & 60 & 0.29 & 131 & -0.20 & -91 \\
\hline \multirow[t]{2}{*}{ Mexico } & 1984-1989 & 0.40 & 100 & 0.66 & 165 & 0.21 & 54 & -0.48 & -119 \\
\hline & 1990-1995 & 0.86 & 100 & 0.35 & 41 & 0.42 & 48 & 0.09 & 11 \\
\hline \multirow[t]{2}{*}{ Peru } & 1983-1988 & 3.11 & 100 & 1.30 & 42 & 1.12 & 36 & 0.70 & 23 \\
\hline & 1989-1994 & 6.90 & 100 & 1.61 & 23 & 3.25 & 47 & 2.04 & 30 \\
\hline \multirow[t]{2}{*}{ Venezuela } & 1983-1988 & 0.36 & 100 & 0.34 & 93 & 1.16 & 320 & -1.13 & -312 \\
\hline & 1989-1994 & 1.77 & 100 & 0.53 & 30 & 0.91 & 51 & 0.33 & 19 \\
\hline
\end{tabular}

Source: Calculated on the basis of data from World Bank (1999), IMF (various years) and IDB (undated).

a The variances and covariances have been multiplied by 100 .

TABLE 6

Latin America and the Caribbean (26 countries): Volatility indicators ${ }^{a}$

\begin{tabular}{|c|c|c|c|c|c|c|}
\hline \multirow[t]{2}{*}{ Country } & \multicolumn{2}{|c|}{ Volatility of GNP } & \multicolumn{2}{|c|}{$\begin{array}{l}\text { Volatility of income } \\
\text { terms of trade }\end{array}$} & \multicolumn{2}{|c|}{$\begin{array}{l}\text { Volatility of private } \\
\text { capital flows }\end{array}$} \\
\hline & $1980 \mathrm{~s}$ & $1990 \mathrm{~s}$ & $1980 \mathrm{~s}$ & $1990 \mathrm{~s}$ & $1980 \mathrm{~s}$ & $1990 \mathrm{~s}$ \\
\hline Argentina & 0.048 & 0.050 & 0.007 & 0.004 & 0.032 & 0.058 \\
\hline Bahamas & 0.028 & 0.023 & & & & \\
\hline Barbados & 0.052 & 0.030 & & & 0.047 & 0.045 \\
\hline Belize & 0.032 & 0.010 & & & 0.031 & 0.011 \\
\hline Bolivia & 0.045 & 0.031 & 0.009 & 0.016 & 0.025 & 0.003 \\
\hline Brazil & 0.044 & 0.039 & 0.008 & 0.003 & 0.009 & 0.040 \\
\hline Chile & 0.070 & 0.027 & 0.021 & 0.029 & 0.049 & 0.018 \\
\hline Colombia & 0.015 & 0.016 & 0.019 & 0.011 & 0.010 & 0.012 \\
\hline Costa Rica & 0.045 & 0.024 & 0.042 & 0.014 & 0.068 & 0.028 \\
\hline Dominican Republic & 0.047 & 0.043 & 0.030 & 0.035 & 0.023 & 0.036 \\
\hline Ecuador & 0.044 & 0.012 & 0.030 & 0.027 & 0.035 & 0.009 \\
\hline El Salvador & 0.027 & 0.007 & 0.039 & 0.022 & 0.026 & 0.009 \\
\hline Guatemala & 0.049 & 0.052 & 0.013 & 0.013 & 0.011 & 0.006 \\
\hline Guyana & 0.026 & 0.024 & 0.063 & 0.197 & 0.058 & 0.051 \\
\hline Haiti & 0.017 & 0.069 & 0.026 & 0.016 & 0.004 & 0.014 \\
\hline Honduras & 0.036 & 0.024 & 0.026 & 0.040 & 0.010 & 0.014 \\
\hline Jamaica & 0.042 & 0.038 & & & 0.039 & 0.024 \\
\hline Mexico & 0.051 & 0.023 & 0.016 & 0.008 & 0.029 & 0.017 \\
\hline Nicaragua & 0.069 & 0.026 & 0.032 & 0.060 & & \\
\hline Panama & 0.083 & 0.053 & 0.021 & 0.019 & & \\
\hline Paraguay & 0.035 & 0.015 & 0.020 & 0.011 & 0.021 & 0.016 \\
\hline Peru & 0.047 & 0.019 & 0.014 & 0.006 & 0.017 & 0.032 \\
\hline Suriname & 0.060 & 0.074 & & & 0.140 & 0.034 \\
\hline Trinidad and Tobago & 0.043 & 0.022 & & & 0.037 & 0.032 \\
\hline Uruguay & 0.055 & 0.028 & 0.026 & 0.008 & 0.037 & 0.033 \\
\hline Venezuela & 0.050 & 0.052 & 0.060 & 0.030 & 0.085 & 0.104 \\
\hline Average & 0.045 & 0.032 & 0.026 & 0.028 & 0.037 & 0.028 \\
\hline Median & 0.045 & 0.027 & 0.023 & 0.016 & 0.031 & 0.024 \\
\hline
\end{tabular}

a The volatility is calculated as the standard deviation of annual GNP growth rates and the income terms of trade, and the standard deviation of gross private capital flows as a proportion of GNP. The information on GNP and the terms of trade is taken from the IDB database, while the data on private capital flows are from World Bank (1999). 
and Venezuela. In Chile, it is the idiosyncratic component of wage movements that exerts the dominant influence.

These calculations and conclusions are necessarily tentative, especially since one would like to carry out the decompositions with household-level data instead of average wages. Nonetheless, they are indicative of the significant and growing role played by macroeconomic instability -in addition to idiosyncratic shocks- in driving income uncertainty for workers in the region. The implication would be that increasing the stability of the macroeconomic environment should make a substantial contribution -perhaps in some cases more than social insurance programmes per se- to the economic security of workers.

Latin America is indeed a region with a very high level of aggregate macroeconomic volatility. While volatility has decreased somewhat since the debt-crisis years, it still remains high in comparative terms. Table 6 shows volatility figures for the countries of the region for the 1980s and 1990s. In unweighted terms, average GNP growth volatility has come down from 4.5 percentage points during the 1980 s to 3.2 points in the 1990s. Even so, this is still twice the level of volatility experienced in an industrial economy such as the United States. Moreover, in a number of significant cases volatility has increased: Argentina and Venezuela are two countries with above-average volatility levels where the 1990s have been even more volatile than the 1980s.

A longer-term comparison with the 1960 s and 1970s is undertaken in table 7 for the larger countries of the region. Rather than presenting raw standard deviations, I have chosen to present the numbers in a somewhat different form. The figures in this table answer the following question: what is the probability in any given year that per capita income will fall by 5\% or more? Since economic insecurity is often based on the fear of a sharp drop in income, this would seem to be a better measure than volatility per se. I have based my calculations on the decadal averages of growth rates and their standard deviation, assuming that annual growth rates are identically and normally distributed. For a given growth rate, the probability of a $5 \%$ decline in income increases with volatility. On the other
TABLE 7

Latin America (8 countries): Economic insecurity in a long-term perspective

(Percentage probability that per capita

income will fall by $5 \%$ in a year)

\begin{tabular}{lrrrr}
\hline & $1960 \mathrm{~s}$ & $1970 \mathrm{~s}$ & $1980 \mathrm{~s}$ & $1990 \mathrm{~s}$ \\
\hline Argentina & 7.9 & 5.4 & 36.5 & 3.3 \\
Brazil & 2.3 & 0.2 & 12.4 & 14.4 \\
Chile & 0.4 & 25.5 & 17.5 & 0.0 \\
Colombia & 0.0 & 0.0 & 0.5 & 0.0 \\
Mexico & 0.0 & 0.0 & 17.1 & 19.0 \\
Peru & 3.5 & 3.6 & 36.5 & 17.8 \\
Uruguay & 4.3 & 0.3 & 28.7 & 0.4 \\
Venezuela & 5.4 & 1.5 & 37.3 & 9.0 \\
Average & 3.0 & 4.6 & 23.3 & 8.0 \\
Median & 2.9 & 0.9 & 23.1 & 6.1 \\
\hline
\end{tabular}

Source: Calculations by the author, based on decadal averages of growth rates of per capita income and their standard deviation, assuming that growth rates are distributed identically and normally over a decade.

hand, for a given level of volatility (expressed as the standard deviation of growth), the same probability is declining in the average growth rate. Hence, the probabilities shown in table 7 combine information from both the growth rate of income and its volatility.

The table reveals that the 1990 s were a vast improvement over the 1980s. But it also makes clear that, for most of the countries shown, aggregate income insecurity was substantially higher in the 1990s than it was during the 1960s and 1970s. In Brazil, Mexico, Peru and Venezuela, the likelihood that average incomes will fall by $5 \%$ or more in any given year is in the range of $10-20 \%$, which is substantially above the levels experienced prior to the 1980s. Only Argentina and Chile can be said to have experienced clear improvements in income security by this measure. Taking the sample of countries as a whole, the average probability of a sharp contraction in income (of $5 \%$ or more) during the 1990s was around twice the levels observed during the $1960 \mathrm{~s}$ and $1970 \mathrm{~s}(8.0 \%$ versus $3.0 \%$ and $4.6 \%$, respectively). 


\section{The sources of macroeconomic volatility: the importance of capital flows}

The causes of macroeconomic volatility in Latin America have been investigated by Hausmann and Gavin (1996). As these authors emphasize, volatility is driven both by external shocks and by domestic policy failures. On the external front, instability in the terms of trade and in capital flows are the key contributors. Some data on these external determinants are shown in table 6. On the policy front, the collapse of pegged exchange rate regimes and erratic monetary policies have generally played a large role. Hence in general exogenous shocks and domestic institutions and policies all matter.

For the 1990s, the evidence suggests that the instability in private capital flows has been perhaps the most important single determinant of macroeconomic volatility. This is the central message that comes out of the regressions shown in table 8.

That table shows the results of regressing averages of GNP growth volatility for each of the two decades (1980s and 1990s) on a number of determinants: the volatility of the income terms of trade, volatility of gross private capital flows, volatility of monetary conditions, financial depth, per capita income, and a dummy for the 1990s. ${ }^{8}$ The first column, which pools the averages for the two decades (and contains up to two observations per country), shows that the volatility of capital flows is a highly significant correlate of GNP volatility. The estimated coefficient of terms-of-trade volatility is positive but insignificant. Financial depth (proxied by M2/GDP) seems not to matter. Volatility of domestic monetary conditions is statistically significant, but only at the $90 \%$ confidence level. The dummy for the $1990 \mathrm{~s}$ is negative and significant, with an estimated coefficient that is roughly equal to the decline in average GNP volatility between the two decades. Finally, there is a negative and significant association between per capita income and volatility. The second column in table 8 drops the insignificant variables (terms-of-trade volatility and financial depth) to gain a few additional ob-

${ }^{8}$ See Easterly, Islam and Stiglitz (1999) for a cross-national analysis of a similar nature. servations. The results remain unchanged. In particular, the volatility of gross private capital flows enters with a highly significant coefficient.

The last two columns of table 8 show the results when the regressions are run decade by decade. We find that the association between GNP volatility and the volatility of private capital flows is particularly strong in the 1990s. In fact, together with per capita income, capital-flow volatility accounts for close to half of the cross-national variation in GNP volatility within Latin America during the 1990s (compared with less than $20 \%$ during the 1980s). The coefficient estimate indicates that a one point increase in the standard deviation of gross private capital flows (as a percentage of GNP) is associated with an increase in the standard deviation of GNP growth rates of more than half a percentage point. The exceptionally strong relationship during the 1990s between the volatility of capital flows and GNP volatility in the region is also shown in figure 2. As that figure shows, some of the smaller countries of the region with little access to private capital flows (Bolivia and Guatemala) have experienced the lowest levels of macroeconomic volatility. Argentina and Venezuela are at the other extreme, with very high levels of exposure to volatility of private capital flows and correspondingly high levels of macro volatility. Countries like

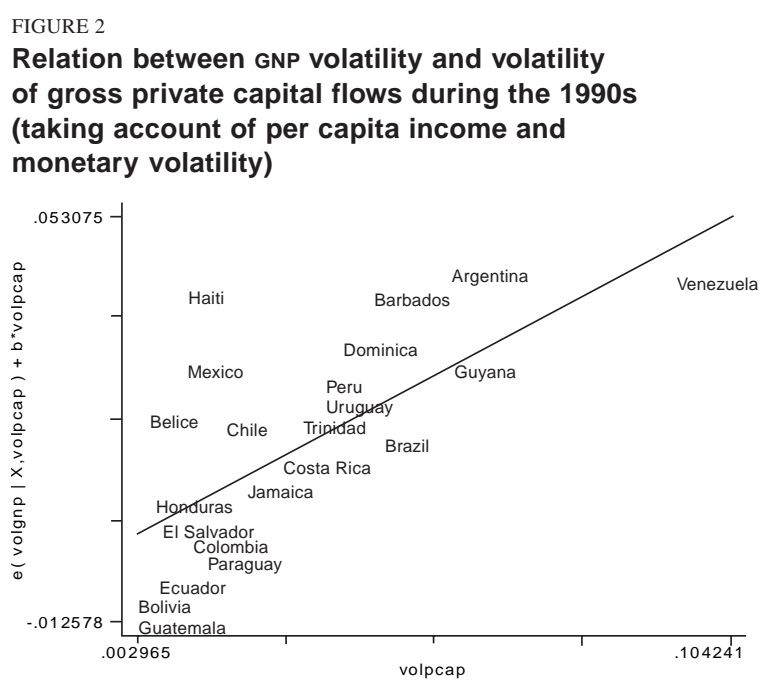


TABLE 8

Latin America and the Caribbean: Determinants of GNP volatility for the 1980 s and $1990 s^{a}$

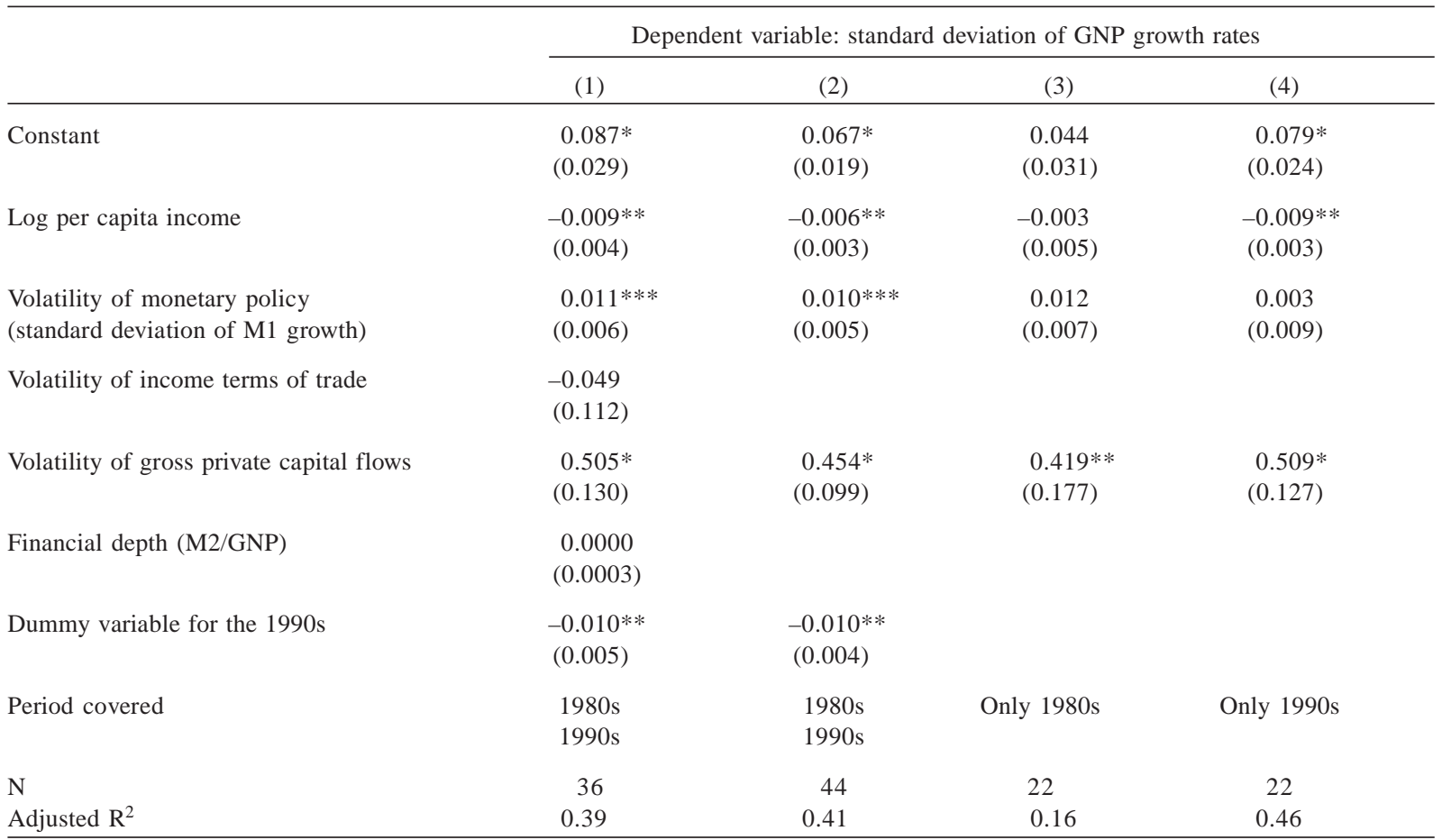

a The regressions use up to two observations per country: one for the 1980s and one for the 1990s. The standard errors are shown in parentheses. The asterisks indicate the level of significance: $*=99 \%$, $* *=95 \%$ and $* * *=90 \%$. The samples used in these regressions excluded four small countries with very volatile private capital flows: Suriname, Panama, Bahamas and Nicaragua.

Brazil, Chile and Colombia, which have managed their private capital flows, are somewhere in between.

It is also possible to interpret these results in a different manner, emphasizing the causality in the opposite direction. Perhaps capital flows simply respond to underlying volatility in the economic environment, and are not a determinant of it. This would be the appropriate interpretation under the assumption that private capital flows follow fundamentals and there are no multiple equilibria, with the result that capital flows are not an independent source of disturbances. Even under this scenario, however, our results indicate that capital flows, by being very sensitive to other shocks, are a potential source of magnification of such shocks. In this sense, countries that are very open to private capital flows may suffer from additional volatility generated by reversals in flows even if capital flows respond only to fundamentals. This point is picked up in greater detail in the following section, which shows how capital mobility aggravates risk for the domestic economy even when capital responds only to exogenous "productivity" shocks. 


\section{VI}

\section{Capital mobility and the incidence of macro risk}

The finding that erratic capital flows are a strong correlate of macroeconomic volatility has an important implication which has to do with the distribution of macroeconomic risk across domestic households. As the decomposition in a previous section highlighted, households whose relative income streams co-vary with the national average bear greater income risk than those whose relative incomes are counter-cyclical. In particular, as my illustrative empirical application highlighted, workers whose real wages are pro-cyclical-rising more than national income in good times, and falling more in bad times- suffer disproportionately from macroeconomic volatility.

One implication of capital mobility is precisely that more of the macro risk gets shifted on to domestic factors of production -such as labour- that are not internationally mobile. Since capital can move in and out in response to, say, domestic productivity shocks, it can evade the risk posed by the stochastic nature of the domestic economic environment. But capital flows thereby impose an externality on internationally immobile groups because the latter now have to bear a greater share of the domestically undiversifiable risk.

A simple model, adapted from Rodrik (1997, chap. 4), illustrates how this works. Let us assume a small open economy that produces (and exports) a single good, whose price is determined in world markets. This good is produced under constant returns to scale, using labour and capital. Unlike labour, capital can move across borders, but at a cost. The magnitude of this cost will be the parameter capturing the degree of capital mobility in the economy. Labour, whose welfare is the focus of the analysis, consumes only the importable. The only source of uncertainty in the model is the productivity level in the exportable sector, which is assumed to be stochastic. Labour income consists of wage income plus the proceeds of a tax on domestic capital.

Let the production function of the exportable sector be written as $p f(k, l)$, with the usual regularity conditions: $f_{k}>0, f_{l}>0, f_{k k}<0, f_{l l}<0$, and $f_{k l}>0$. The stochastic productivity parameter is given by $p$. (We could equivalently think of $p$ as the terms of trade.) We normalize the economy's fixed labour endowment to unity, so the production function can also be expressed as $p f(k)$. The domestically-owned capital stock is exogenously fixed at $k_{0}$. Note that $k$, the capital used at home, can differ from $k_{0}$ as capital moves in and out of the country. A key assumption is that an increasing cost is incurred by capitalists as capital moves across borders. We can think of this as the cost of setting up business in a less familiar environment, the cost incurred in transporting the final goods back to the home economy, the cost of communicating with subsidiaries in a different country, etc. Increased capital mobility will be captured in the model by reductions in the parameter $\lambda$.

The model can be described in three equations:

$$
\begin{gathered}
r=p f_{k}(k)-\tau \\
r=r^{*}-\lambda\left(k_{0}-k\right) \\
w=p f_{t}(k)
\end{gathered}
$$

The domestic return to capital $(r)$ is given by the marginal value product of capital net of the domestic tax. International trade in capital services requires that this return be equal to the international return $\left(r^{*}\right)$ minus a margin that is related to the cost of moving capital abroad. Hence a capital outflow which reduces the capital stock at home to $k_{1}$ would depress the rate of return earned by domestic capitalists to $r^{*}-\lambda\left(k_{0}-k_{1}\right)$. Equation [2] expresses this arbitrage condition. Finally, equation [3] states that the domestic wage $(w)$ equals the marginal value product of labour. These three equations determine the three endogenous variables in the system, $w, r$, and $k$.

Figure 3 presents a graphical view of the way the model works. The downward sloping schedule shows the negative relationship between $r$ and $k$ expressed in equation [1]. As domestic productivity $(p)$ moves around, so does this schedule. Intuitively, for any given amount of capital invested at home, the return to capital fluctuates in tandem with the productivity in the exportable sector. The upward sloping schedule, for its part, represents the relationship expressed in equation [2]. Two versions of this schedule are shown, one for high $\lambda$ (low capital mobility) and one for low $\lambda$ (high 
capital mobility). The lower is $\lambda$, the flatter this schedule. At the limit, with capital fully mobile at zero cost, the schedule would be horizontal and it would fix the domestic rate of return at $r^{*}$.

Let us denote by $k(p, \tau, \lambda)$ the equilibrium level of capital employed at home. Consider an initial equilibrium where the combination of parameters is such that $k(p, \tau, \lambda)=k_{0}$. In this equilibrium, denoted by $\mathrm{A}$ in figure $3, r=r^{*}$. Changes in $\lambda$ would have no effect on $w$ or $k$ (or $r$ ) starting from this initial equilibrium, since

$$
\begin{array}{r}
\frac{d k}{d \lambda}=\frac{k-k_{0}}{p f_{k k}-\lambda}, \\
\frac{d w}{d \lambda}=p f_{k l}\left[\frac{k-k_{0}}{p f_{k k}-\lambda}\right]
\end{array}
$$

and both expressions equal zero when $k=k_{0}$. Intuitively, we fix the initial equilibrium such that capital has no incentive to move in or out of the domestic economy, and consequently changes in the cost of mobility are of no consequence (holding $p$ constant).

Now let us consider what happens as $p$ fluctuates. A reduction in $p$ drives down the domestic return to capital and results in a capital outflow, the magnitude of which is inversely proportional to $\lambda$. As the figure demonstrates, the greater the mobility of capital, the wider the fluctuations in the domestic capital stock in response to changes in the world price. Formally,

$$
\frac{d k}{d p}=\frac{f_{k}}{\lambda-p f_{k k}}>0,
$$

which is decreasing with respect to $\lambda$. The consequences for labour can be easily deduced. Since the domestic wage (in terms of the importable) is determined by the value marginal product of labour in the exportable (equation [3]), capital mobility accentuates the fluctuation in the consumption wage. The lower is $\lambda$, the wider the amplitude of fluctuations in $w$ :

$$
\frac{d w}{d p}=f_{l}+\frac{p f_{k l} f_{k}}{\lambda-p f_{k k}}>0,
$$

which is decreasing in $\lambda$.
FIGURE 3

Functioning of the model

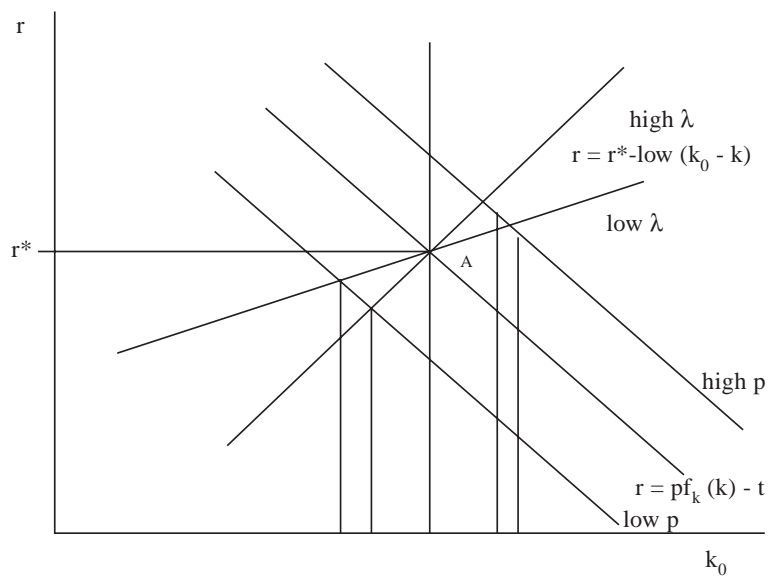

In fact, things are even worse for labour, insofar as part of workers' income comes from the tax on capital. Denoting workers' total (real) income by $I$,

$$
I=w+\tau k
$$

Fluctuations in $I$ therefore result not only from fluctuations in wages, but also from fluctuations in the tax base $(k)$ as capital moves back and forth in search of higher returns.

Hence, by rendering capital more responsive to changes in domestic productivity, capital mobility magnifies the amplitude of fluctuations in workers' incomes at home. The effect arises because workers' incomes depend not only on domestic productivity, but also on (a) the domestic capital stock, which fluctuates in response to productivity shocks; and (b) the economy's tax base, which also fluctuates to a greater extent as a result of capital mobility. The effect of capital mobility is increased exposure of labour to macro risk. This can be appropriately viewed as a negative externality that capital imposes on labour. Moreover, when capital mobility is sufficiently high, it becomes impossible to compensate labour through suitable adjustments in the tax on capital: capital mobility allows capitalists to evade the tax, which leaves workers even worse off. The model thus captures in schematic fashion a policy dilemma faced all around the world, but especially strongly in Latin America, where the volatility of capital flows is particularly significant. 


\section{VII}

\section{Exchange rates, capital mobility and macroeconomic volatility}

The association between exchange-rate policy and macroeconomic volatility has already been noted: the collapse of unsustainable currency pegs has historically been an important source of instability for Latin American countries. One of the findings of Hausmann and Gavin (1996) is that countries with flexible exchange rates have typically experienced lower GDP volatility than countries with fixed rates. One reason has to do with the avoidance of currency crises. The other is that flexible exchange rates provide greater insulation against real shocks: a decline in productivity in tradeables sectors or the terms of trade can be met by immediate currency depreciation, short-cutting an adjustment process that under fixed rates would have to be effected through domestic price changes and would take much longer.

Capital mobility in the 1990s has undercut the ability of flexible exchange rates to perform that stabilizing function. Where they are not fixed, currency values have been driven less by shocks to competitiveness or changes in the trade balance and more by considerations of maintaining short-term capital flows and investor confidence. Michael Gavin summarizes the response in the region to the shocks since the Asian crisis as follows:

"The first stylized fact is that despite the magnitude of the external shocks, most countries used their exchange rate flexibility very sparingly... In Peru - a formally floating rate country that was severely hit by both El Niño and the collapse in the terms of trade - the cumulative devaluation barely kept pace with inflation. Chile also allowed minimal movements in its exchange rate in spite of a major collapse in the price of copper and in the Asian demand for its exports" (Gavin, 1999, p. 3 ; italicized in the original).

Gavin goes on to discuss how the policy response of choice was instead the interest rate, which was used aggressively to defend the exchange rate. In other words, rather than letting the nominal exchange rate depreciate sufficiently to give the real economy a boost, Latin American governments chose to tighten monetary conditions to prevent depreciation. Exchange-rate policy was de-linked from the needs of the real economy.

Table 9 provides a more systematic look at this by analyzing the correlation between real exchange rate changes and balance-of-payments flows of different kinds. The exercise is inspired by a similar one reported in ILO (1999, table 3), which however covers only a single Latin American country. It consists of calculating the correlation coefficients between the quarterly movements in the real exchange rate and flows of two kinds: "real" flows and "financial" flows. The first category of flows is defined as the sum of the current account and inward foreign direct investment (FDI). The second category covers all capital account movements except FDI and reserve changes, and includes errors and

TABLE 9

Latin America (6 countries): Correlations between the real exchange rate and balance of payments flows

\begin{tabular}{lccc}
\hline & \multicolumn{3}{c}{$\begin{array}{c}\text { Coefficient of correlation between the } \\
\text { real exchange rate and: }\end{array}$} \\
\cline { 2 - 4 } & $\begin{array}{c}\text { Current account } \\
+ \text { FDI }\end{array}$ & $\begin{array}{c}\text { Financial } \\
\text { inflows }\end{array}$ & Period $^{\text {b }}$ \\
\hline Argentina & 0.19 & $-0.52^{*}$ & 89Q2-98Q4 \\
Brazil & $0.40^{* * *}$ & -0.23 & $93 Q 1-97 Q 4$ \\
Chile & -0.24 & -0.03 & $89 Q 1-98 Q 4$ \\
Mexico & $0.68 *$ & $-0.69 *$ & 89 Q1-98Q4 \\
Peru & 0.40 & 0.21 & $94 Q 1-97 Q 4$ \\
Venezuela & 0.24 & -0.06 & $94 Q 1-98 Q 4$ \\
\hline
\end{tabular}

Source: Calculated on the basis of data from IMF (various years).

a The exchange rates are defined in terms of units of national currency per unit of foreign currency, so that an increase represents a depreciation in real terms. Financial inflows correspond to all capital account movements other than FDI inflows and variations in reserves, including errors and omissions. The periods were selected according to the availability of quarterly data. The levels of statistical significance were as follows: $*=99 \%, * *=95 \%, * * *=90 \%$.

b $\mathrm{Q}=$ quarter. 
omissions. ${ }^{9}$ The exercise is carried out for all of the major Latin American countries for which the IMF's International Financial Statistics report the relevant quarterly data for some time during the 1990s. There are six countries in all.

The results tell a consistent story. The correlation between financial flows and real exchange rate movements is negative in all but one case (Peru is the sole exception). This indicates that there is a general tendency for the real exchange rate to appreciate in response to financial inflows. The correlation between the real exchange rate and real flows, on the other hand, is positive in five out of six cases (Chile is the sole exception in this case). In other words, in all countries except Chile, deteriorations in the current account (and the FDI balance) are associated with an appreciation of the real exchange rate.

What these results seem to reflect is an increasingly common pattern where financial flows are in the driving seat for the real exchange rate. As far as stabi- lizing demand for domestic output is concerned, the exchange rate tends to move in the "correct" direction in the case of financial flows -a reduction in inflows depreciates the real exchange rate- but in the "wrong" direction in the case of trade flows: a deterioration in the current account is accompanied by appreciation of the real exchange rate. This pattern is clearest in the case of Mexico, where increasing financial inflows and current account deterioration between 1988 and 1994 were matched with an ongoing real appreciation of the currency. This is picked up in table 9 in the form of very strong correlations between these flows and the real exchange rate. Of course, it is possible to interpret Mexico's experience as an equilibrium appreciation of the currency in anticipation of future productivity gains, notwithstanding the eventual peso crisis. It is nonetheless the case that the real exchange rate was governed by short-term investors' expectations rather than by the state of domestic demand or the large and growing current account deficit.

\section{VIII}

\section{Exchange rate flexibility as social insurance}

The operation of exchange rate policy during the 1990s has contributed to greater economic insecurity in the region in a more subtle fashion as well. An exchange rate that is targeted on the real economy not only serves a stabilization function; it also serves a social insurance function. The reason is that when the exchange rate follows the behaviour of the current account, shocks to the competitiveness of individual industries are dissipated throughout the entire economy via changes in the value of the currency. On the other hand, when the exchange rate is fixed or is responsive mainly to financial flows, the affected industries have to bear the full brunt of the shock. Since this point is not widely recognized, I will develop it using a simple model.

Let us consider a small open economy that produces two tradeable goods (denoted by 1 and 2) and a single non-tradeable good (denoted by $n$ ). We will as-

\footnotetext{
${ }^{9}$ Note that since changes in reserves are excluded from the calculations, the two sets of correlations need not produce symmetrical results (identical in absolute value and opposite in sign).
}

sume for simplicity's sake that neither of the two tradeable goods is consumed at home, and that the total domestic output of these goods is exported. Households consume the non-tradeable good as well as an imported good that is not produced at home. We fix the (exogenous) world prices of the tradeable goods at unity. Let $e$ stand for the nominal exchange rate in units of home currency per foreign currency unit. The domestic price of all three tradeable goods (the two exportables and the importable) is then given by $e$. Let the price of the non-tradeable be $p$.

We will simplify the structure of the economy further by assuming that labour is the only factor of production, and that each of three productive sectors at home uses labour specific to that particular activity. There is no intersectoral mobility of labour. Let the inelastically supplied labour of each type be given by, $\bar{l}_{1}, \bar{l}_{2}$ and $\bar{l}_{n}$, with associated wages $w_{1}, w_{2}$, and $w_{n}$, while labour productivity in the three sectors is given by $a_{l}$, $a_{2}$, and 1 , respectively.

To allow nominal exchange-rate policy to have real effects, we shall assume that $w_{1}$ and $w_{2}$ are rigid down- 
wards. The implication is that when unit labour costs exceed prices in either one of the export sectors, labour in that sector will become unemployed. Formally,

$$
l_{1}=\left\{\begin{array}{l}
\bar{l}_{1} \text { if } w_{1} \leq e a_{1}, \\
0 \text { otherwise }
\end{array}\right.
$$

and similarly for the other export sector:

$$
l_{2}=\left\{\begin{array}{l}
\bar{l}_{2} \text { if } w_{2} \leq e a_{2}, \\
0 \text { otherwise }
\end{array}\right.
$$

Labour in the non-tradeable sector is always fully employed, and the price-cost relationship in that sector is given by

$$
w_{n}=p
$$

Note that the inequalities in (2.1) and (2.2) will hold as equalities as long as labour of the respective type is not unemployed.

To close the model, we need to specify equality between demand and supply. We shall assume that trade balance holds, so that it is sufficient for our purposes to state the equality between supply and demand for tradeables. Let $Y=e a_{1} l_{1}+e a_{2} l_{2}+p l_{n}$ stand for aggregate income, and $D(e, p, Y)$ for the demand function for importables. The trade balance equation is:

$$
a_{1} l_{1}+a_{2} l_{2}-D(e, p, Y)=0
$$

It will be convenient to work with a specific functional form, so we will assume that preferences are CobbDouglas. Let $\alpha$ stand for the budget share of importables, so that $D()=.\alpha Y / e$. Then the trade-balance equation can be written as follows:

$$
(1-\alpha) a_{1} l_{1}+(1-\alpha) a_{2} l_{2}-\alpha\left(\frac{p}{e}\right) \bar{l}_{n}=0
$$

To see how the model works, let us first consider the case with no wage rigidity. Then we have full employment with $\bar{l}_{1}=l_{1}$ and $l_{2}=\bar{l}_{2}$, and equation [2.4] determines the "real exchange rate" $(e / p)$ as a function of labour productivities $a_{1}$ and $a_{2}$. A decrease in the productivity of either of the export sectors results in a depreciation of the real exchange rate (a rise in $e / p$ ). Equations [2.1]-[2.3] give us three additional equations with additional endogenous variables $w_{1}, w_{2}$, and $w_{n}$. We have a total of four equations and five prices (the three wages plus $p$ and $e$ ), so only four relative prices can be determined. It does not matter whether the nominal exchange rate or one of the wage rates is used as the numerator.

For future reference, let us carry out a static comparative analysis of the case with no nominal rigidity (the solutions for this case will remain valid under wage rigidity as well, as long as no downward adjustment in tradeable-sector wages is called for in equilibrium). Let us consider a change in $a_{1}$, with $a_{2}$ remaining unchanged. We will define $\theta \equiv \frac{a_{1} \bar{l}_{1}}{a_{1} \bar{l}_{1}+a_{2} \bar{l}_{2}}$, with $1>\theta>0$. Then it can be shown that relative prices move as follows.

$$
\begin{gathered}
\hat{w}_{1}-\hat{e}=\hat{a}_{1} \\
\hat{w}_{1}-\hat{p}=(1-\theta) \hat{a}_{1} \\
\hat{w}_{2}-\hat{e}=0 \\
\hat{w}_{2}-\hat{p}=\theta \hat{a}_{1} \\
\hat{w}_{n}-\hat{e}=\theta \hat{a}_{1} \\
\hat{w}_{n}-\hat{p}=0,
\end{gathered}
$$

where a hat indicates a proportional change ( $\hat{x} \equiv d x / x)$. These relationships enable us to determine the implications for the real wages, and hence the welfare, of each of the three groups of workers.

Suppose productivity in sector 1 decreases $\left(\hat{a}_{1}<0\right)$. We see from equations [2.5] and [2.6] that workers in sector 1 lose unambiguously. Workers in the other export industry (sector 2) benefit, however, since their wage stays unchanged in terms of the importable but rises in terms of the non-tradeable good (see equations [2.7] and [2.8]). Workers in the nontradeable sector lose, due to the real depreciation of the exchange rate. These results are independent of the "exchange rate regime", since in a model without wage rigidity, the nominal exchange rate has no real effects whatsoever.

\section{Nominal wage rigidity and fixed exchange rates}

Let us consider now what happens when we require that wages in both tradeable sectors be rigid downwards, that is, $\hat{w}_{1} \geq 0$ and $\hat{w}_{2} \geq 0$. The exchange rate now matters because under a fixed-rate regime (with $\hat{e}=0$ ), the downward adjustment of wages in relation to tradedgood prices is blocked. Since such an adjustment is 
required in order to maintain full employment when an industry receives a negative productivity shock, the outcome will be unemployment.

Comparative static analysis of this case, with $\hat{a}_{1}<0$ as before, yields the following results under fixed exchange rates:

$$
\begin{gathered}
d l_{1}=-\bar{l}_{1} \\
\hat{w}_{2}-\hat{e}=0 \\
\hat{w}_{2}-\hat{p}=\theta \hat{a}_{1}+\theta \\
\hat{w}_{n}-\hat{e}=\theta \hat{a}_{1}-\theta \\
\hat{w}_{n}-\hat{p}=0 .
\end{gathered}
$$

We note three changes. First, all workers in industry 1 lose their jobs (equation 2.11). Second, workers in industry 2 now experience an even larger gain in real wages (compare equations 2.8 and 2.8', remembering that $\left.\hat{a}_{1}<0\right)$. Third, workers in the non-tradeable sector experience a bigger drop in real wages (compare 2.9 and 2.9'). The last two results are due to a sharper change in the real exchange rate when wage rigidity combined with fixed exchange rates results in unemployment. The intuition is as follows: when export industry 1 collapses as a result of becoming uncompetitive, the incipient trade deficit is much larger, and the requisite relative-price correction is commensurately bigger.

The important result from our perspective is that the distributional implications of the productivity shock are accentuated. Wage rigidity combined with fixed exchange rates results not only in inefficient outcomes (captured here by unemployment), but also in greater dispersion of the distributional outcomes.

\section{Nominal wage rigidity and flexible exchange rates}

When the exchange rate is not fixed and can be targeted on the trade balance, these effects can be offset by a depreciation of the nominal exchange rate that is large enough to restore unit labour costs in industry 1 to their original level (i.e., $\hat{e}=-\hat{a}_{1}$ ). Flexibility in $e$ allows the wage in sector 1 to be reduced in terms of traded-goods prices, eliminating unemployment. Therefore, equations [2.5] to [2.10] continue to describe the behaviour of the economy, despite downward rigidity in $w_{1}$. The distributional outcomes are the same as in the absence of wage rigidity.

The results with productivity shocks to sector 2 are analogous, and need not be discussed in detail. Table 10 summarizes the distributional impacts for the three sectors, under both positive and negative shocks. Note that under positive productivity shocks, the distributional impacts do not depend on whether the exchange rate is fixed or targeted on the trade balance. This is because of the (plausible) assumption that wages are rigid downward but not upward. Consequently, nonclassical results obtain under fixed exchange rates only when one of the sectors is hit with a negative shock. When that happens, the distributional effects are aggravated under fixed rates through the two channels mentioned above: first, incomes collapse in the adversely affected sector because of unemployment, and second, there is a larger relative price change to the benefit of the other tradeable sector and the detriment of the non-tradeable sector.

TABLE 10

Distributional implications of productivity shocks under different exchange-rate regimes

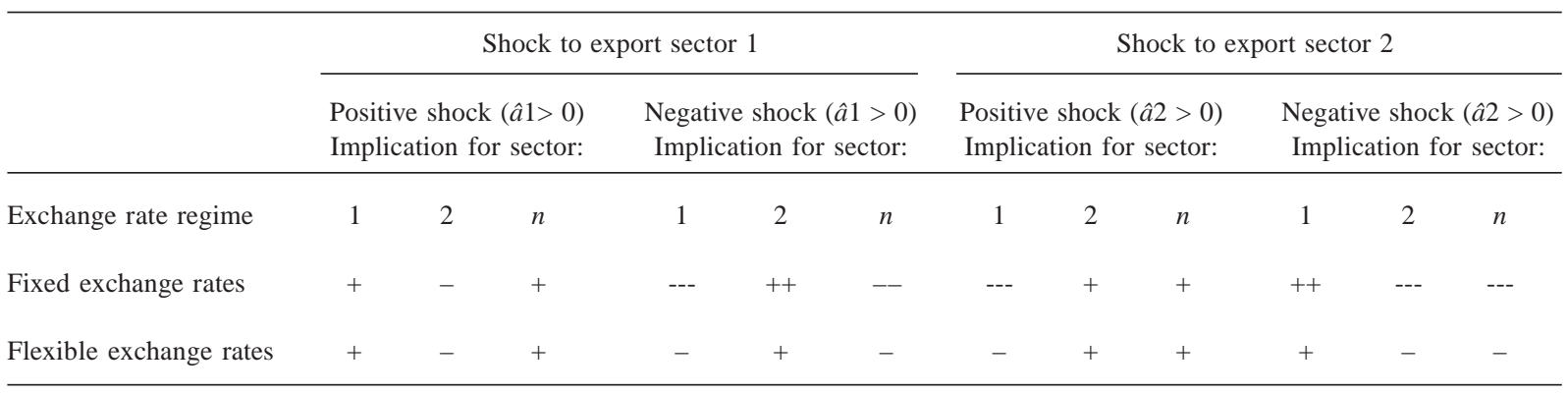

a The model assumes that nominal wages are rigid downwards in sectors 1 and 2. See text for description of model and discussion. 


\section{IX}

\section{Institutions of voice}

The demise of military rule and the transition to democracy have been the most encouraging developments to take place in Latin America during the last two decades. Cross-national evidence suggests strongly that societies with greater political openness and participation are better at adjusting to external shocks, experience lower economic volatility, and generate lower inflation (Rodrik, 1998). Hence, the institutionalization of democracy should eventually produce more stable economic outcomes and alleviate economic insecurity in the region.

The international evidence on the relationship between type of political regime and economic stability is shown in figures 4 and 5. These scatter plots display the (partial) association between a measure of non-elite political participation and two indicators of macroeconomic volatility over the span of two decades (1970s and 1980s). The volatility measures are the standard deviation of real GDP growth rates (figure 4) and the average inflation rate (figure 5). The measure of participation (parcomp) is an index taken from the Polity III data set of Jaggers and Gurr (1995), and is defined as the "extent to which non-elites are able to access institutional structures for political expression". The latter is highly correlated with usual measures of democracy (such as the commonly used Freedom House index), but I have found that it is a better predictor of macroeconomic volatility than others. The regressions on which the scatter plots are based contain the following additional controls: per capita income, population size, terms-of-trade volatility, and regional dummies for Latin America, Africa, and East Asia. The scatter plots show the association between political participation and volatility, controlling for these other variables.

Political participation turns out to be strongly, and negatively, correlated with both GDP volatility and inflation levels. While correlation does not prove causation, other econometric work and a range of case studies suggest that the degree to which a political system is open to participation from below does affect the quality of macroeconomic management for the better (see Rodrik, 1999, and references therein). Participation helps in a number of different ways. First, democracy allows a smooth transfer of power from failed policies and politicians to a new group of government leaders.
FIGURE 4

Relationship between GDP volatility and political participation, 1975-90 (96 countries)

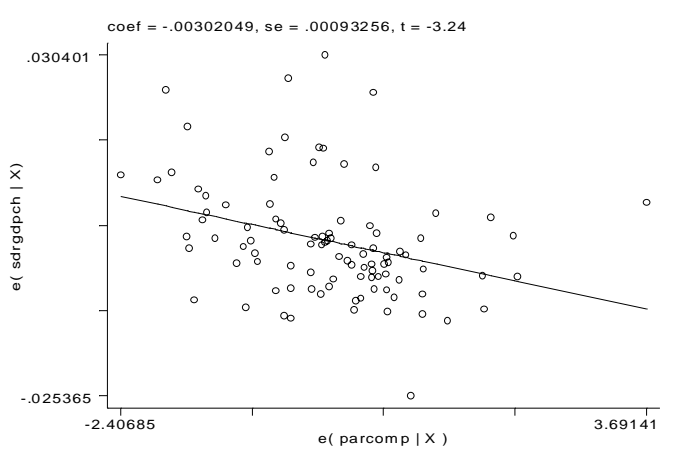

FIGURE 5

Relationship between inflation and political participation, 1970-90 (96 countries)

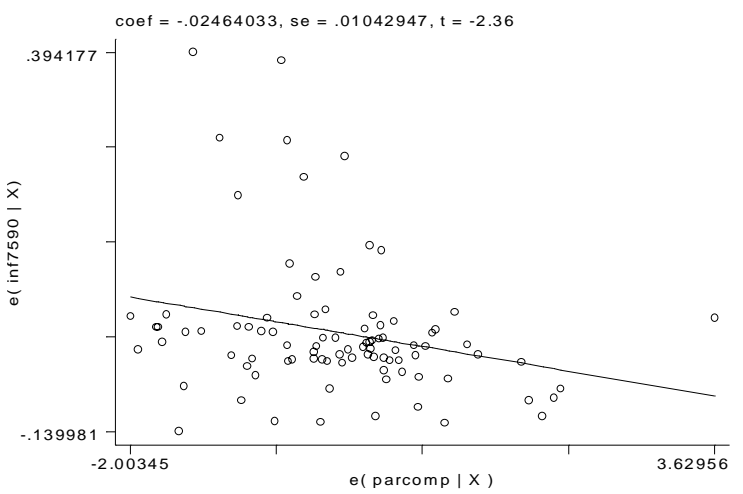

Second, participation enables mechanisms of consultation and bargaining, allowing policy makers to fashion the consensus needed to undertake the necessary policy adjustments in a decisive manner. Third, institutionalized mechanisms of "voice" obviate the need for riots, protests, and other kinds of disruptive actions by affected groups, as well as lowering the support for such behaviour by other groups in society.

Participatory institutions in Latin America still have a number of important weaknesses, however, despite 
the region's transition to democracy. These weaknesses have to be seen as one of the elements aggravating economic insecurity: when large segments of the population lack an effective mechanism of voice in matters that affect them, they naturally feel less in control of their fate.

As already noted, trade unions, which are an important institution of collective voice, have lost membership in all countries for which data are available, except Chile. Unions are important to workers not only because they act as pressure groups in the political sphere, but also because they enable participation in decision making in the workplace. On both accounts, unions provide their members with a greater sense of control over their working environment. As Pencavel (1997, p. 58) puts it in his discussion of Latin America:

"It is important... that workers not feel alienated from the economic and social system and [that they] believe they have a stake in it. Process matters: even if outcomes are identical, employees value the fact that they or their agents help to shape their working environment. The labour union has been the primary vehicle for accomplishing this situation".

The old style of trade union activity in Latin America, consisting of lobbying for legally mandated forms of job protection and wage advantages, is arguably not well suited to the requirements of economies with competitive markets and smaller production units. In the past, unions have been too often associated with populist and protectionist policies. As Márquez and Pages (1998) argue, neither trade union leaders nor policy makers have yet been able to fashion an environment in which unions are seen as sufficiently responsive to the needs of workers as a group.

The broader political system in Latin America is faced with what Domínguez (1997) calls a "crisis of representation". As he puts it, "long-standing forms of representation -populist parties and so-called corporatist arrangements- have weakened precisely at the moment when public support must be found to help guarantee the stability of economic reforms and constitutional government ..... Government officials in Latin America are perceived as corrupt, political parties as a collection of factions, legislatures as ineffective, and presidents as either saviors or rascals to be impeached. While military coups have all but disappeared, new forms of threats to constitutionalism have emerged: rule by Presidential decree, mutinies led by disgruntled middle-ranking military officers, and Presidential "coups" against the legislature, courts and all vehicles that help civil society seek advocacy and representation for its interests" (Domínguez, 1997, pp. 109-112). Mutinies from within the military have taken place in Argentina, Ecuador, Guatemala, Panama and Venezuela, while presidential coups have been attempted in Guatemala, Peru and Venezuela.

Colonel Hugo Chávez, a Venezuelan paratrooper, typifies all these trends: in 1992 he unsuccessfully tried to topple the democratically elected government of Venezuela. Even though he failed, his attempt was sufficiently popular to carry him to a clear majority in the presidential elections of 1998. In late 1999, Chávez still maintained high popularity ratings despite his decision to effectively disband the legislature and replace it with a constitutional assembly elected to draft a new constitution. This is indicative of the frustration that Latin Americans evidently feel regarding their political systems.

As in so many other instances, Chile stands out as an exception to many of these trends. The transition to democracy in Chile in 1990 was accompanied by the initiation of a social dialogue between labour, business and the government and a series of annual tripartite agreements. The democratically-elected government of Patricio Aylwin sought to gain social legitimacy for its economic policies by increasing spending on social programmes and by drawing on the labour movement. The Aylwin government's first significant piece of legislation was a tax increase earmarked for greater social spending (Domínguez, 1998). The tripartite agreements allowed the unions to participate in national decision making over such matters as the raising of the minimum wage and the reform of labour laws. In the words of Cortázar (1997), the centre-left coalitions that have run Chile since 1990 have looked on labour unions as an "opportunity for, rather than a threat to, development". Employers, for their part, have found it convenient in the post-Pinochet period to have a social partner across the negotiating table in order to avoid social strife. The result has been a comparatively harmonious system of labour relations ${ }^{10}$ and a political system that has perhaps a surprising amount of popular legitimacy despite its failure to come to grips with Pinochet's legacy.

\footnotetext{
${ }^{10}$ A 1997 survey, carried out among 300 private-sector companies in Santiago, found that an astonishing $83.7 \%$ of employers consider labour unions to help labour relations, and only $6 \%$ believe that they make them more difficult. Among trade union leaders, $65.3 \%$ said that most of the time employers facilitate the work of trade unions. (Reported in The Economist Intelligence Unit, 1998).
} 


\section{$\mathrm{X}$}

\section{Concluding remarks}

I have argued in this paper that economic insecurity in Latin America is multifaceted and has many sources that feed on each other. Some of the insecurity arises from the decline in employment protection and increased volatility of household outcomes. Some of it is the result of erratic capital flows and the systemic instability generated by a divorce between the instruments of stabilization and the real economy. Finally, an important component is the weakness of the institutions of voice and representation.

An important implication of this is that programmes aimed at social protection per se can be of partial help only. Well-functioning safety nets -unemployment compensation, old-age and medical benefits, targeted social funds- may help cope with some of the idiosyncratic risks that households face. But they will have to be complemented by macroeconomic policies (with regard to capital flows and the exchange rate in particular) that are more conducive to the stability of the real economy and by loosening the control of financial markets over the instruments of macroeconomic policy. They will also require access to representative institutions — trade unions, political parties, and legislatures - with greater responsiveness and legitimacy than those that exist at present.

Perhaps what Latin America needs most, however, is a vision of how social cohesion can be maintained in the face of large inequalities and volatile outcomes, both of which are being aggravated by the growing reliance on market forces. In today's advanced industrial countries, the expansion of the market's role has historically gone hand in hand with the strengthening of the institutions of social insurance. Since the New Deal in the United States, and even more so since World War II in Europe, that has meant the growth of the public sector and the erection of a welfare state. If Latin America is to carve a different path for itself, the region will have to develop an alternative vision that articulates how the tension between market forces and the yearning for economic security can be eased.

The good news is that this question is at least being addressed. The bad news is that no-one, least of all economists, has a very useful answer to offer so far.

(Original: English)

\section{Bibliography}

Amadeo, E. J. and J. M. Camargo (1997): Brazil: regulation and flexibility in the labor market, in S. Edwards and N. Lustig (eds.), Labor Markets in Latin America, Washington, D.C., Brookings Institution.

Bordo, M. D., C. Goldin and E. N. White (eds.) (1998): The Defining Moment: The Great Depression and the American Economy in the Twentieth Century, Chicago, Illinois, University of Chicago Press.

Cortázar, R. (1997): Chile: The evolution and reform of the labor market, in S. Edwards and N. Lustig (eds.), Labor Markets in Latin America, Washington, D.C., Brookings Institution.

Domínguez, J. (1997): Latin America's crisis of representation, Foreign Affairs, vol. 76, No. 1, New York, Council on Foreign Affairs, Inc.

(1998): Free politics and free markets in Latin America, Journal of Democracy, vol. 9, No. 1, New York, Council of Foreign Relations, October.

Easterly, W., R. Islam and J. E. Stiglitz (1999): Shaken and Stirred: Volatility and Macroeconomic Paradigms for Rich and Poor Countries, Michael Bruno Memorial
Lecture, XII World Congress of the IEA, Buenos Aires, International Association for the Evaluation of Educational Achievement (IEA), 27 August.

Ferreira, F. H. and R. Paes de Barros (1999): The Slippery Slope: Explaining the Increase in Extreme Poverty in Urban Brazil, 1976-1996, Texto para discussão, No. 404, Rio de Janeiro, Catholic University of Rio de Janeiro.

Gavin, M. (1999): Latin American central banks: Reticent to react, Latin American Economic Policies, vol. 7, Washington, D.C., Inter-American Development Bank (IDB), Office of the Chief Economist.

Gavin, M. and R. Hausmann (1996): Sources of Macroeconomic Volatility in Developing Economies, Washington, D.C., IDB.

Glewwe, P. and G. Hall (1998): Are some groups more vulnerable to macroeconomic shocks than others? Hypothesis tests based on panel data from Peru, Journal of Development Economics, vol. 56, No. 1, Amsterdam, The Netherlands, Elsevier Science Publishers, B.V.

Hausmann, R. and M. Gavin (1996): Securing Stability and 